\title{
Fiber composition and digestibility of fodder in different ryegrass fields submitted to different harvesting management systems
}

\author{
[Composição da fibra e digestibilidade da forragem de diferentes cultivares de azevém \\ submetidos a diferentes sistemas de manejo de colheita] \\ M. Neumann ${ }^{1}$, A. Dochwat ${ }^{2}$, L.C. Santos ${ }^{2}$, A.M.Souza ${ }^{2}$, R.K. Ueno ${ }^{3}$, \\ R. Carletto ${ }^{3}$, A.D. Manchur ${ }^{4}$, C. Czelusniak ${ }^{4}$ \\ ${ }^{1}$ Universidade Estadual do Centro-Oeste - Guarapuava, PR \\ ${ }^{2}$ Programa de pós-graduação - Universidade Estadual do Centro-Oeste - Guarapuava, PR \\ ${ }^{3}$ Cooperativa Agroindustrial Aliança de Carnes Nobres Vale do Jordão - Guarapuava, PR \\ ${ }^{4}$ Programa de graduação - Universidade Estadual do Centro-Oeste - Guarapuava, PR
}

\begin{abstract}
This essay aims to evaluate the composition of fiber in neutral detergent, digestibility of plant components, as well as ruminal disappearance rate of fodder dry matter from five ryegrass fields submitted to different cut systems for the production of haylage. The experimental design was the randomized blocks one, at a $5 \times 3$ factorial scheme, with five cultivars (cv.) of ryegrass Lolium multiflorum (cv. Barjumbo, cv. BarHQ, cv. Ribeye, cv. Potro and cv. Willians) associated with three harvesting management systems: 1- single harvesting system at a pre-floral stage; 2 - double harvesting system, with a cut at vegetative stage and another at pre-floral stage; and 3 - triple harvesting system, with a cut at vegetative stage, a cut at full vegetative stage and a cut at pre-floral stage, with three repetitions each. Similarities were noticed on the results of fodder digestibility of different fields, however, cv. Potro presented a higher ruminal disappearance rate after 48 hours, with $69.27 \%$. Generally, the harvesting management system with the increase of ryegrass cut frequency determined increments on the percentage of lignin and the reduction in the concentration of total nutrients and dry matter digestibility of the resulting hylage.
\end{abstract}

Keywords: ruminal disappearance, winter fodder, lignin

\section{RESUMO}

O objetivo do presente trabalho foi avaliar a composição da fibra em detergente neutro, digestibilidade dos componentes da planta, bem como a taxa de desaparecimento ruminal da matéria seca da forragem de cinco cultivares de azevém submetidos a diferentes sistemas de cortes para produção de silagem présecada. O delineamento experimental foi em blocos ao acaso,, em um fatorial $5 \times 3$, sendo cinco cultivares de azevém Lolium multiflorum (cv. Barjumbo, cv. BarHQ, cv. Ribeye, cv. Potro e cv. Willians) associados a três sistemas de manejo de colheita: 1 - sistema com única colheita no estádio de pré-florescimento; 2 sistema com uma colheita no estádio vegetativo e outra no estádio de pré-florescimento; e 3 - sistema com uma colheita no estádio vegetativo, uma no estádio pleno vegetativo e outra no estádio de préflorescimento, com três repetições cada. Notou-se similaridade entre os resultados de digestibilidade da forragem entre os cultivares, porém o cv. Potro apresentou a maior taxa de desaparecimento ruminal após 48 horas, com 69,27\%. De maneira geral, o sistema de manejo de colheita mostrou que o aumento do número de cortes do azevém determinou incrementos nos teores de lignina e redução na concentração de nutrientes digestíveis totais e da digestibilidade da matéria seca nas silagens pré-secadas resultantes.

Palavras-chave: desaparecimento ruminal, forragem de inverno, lignina

Recebido em 6 de dezembro de 2018

Aceito em 8 de agosto de 2019

*Autor para correspondência (corresponding author)

E-mail: andrems_92@hotmail.com 


\section{INTRODUCTION}

Ryegrass is a fodder winter plant, majorly cultivated in temperate and subtropical areas of the globe (Bressolin, 2007). The two main species are from the Lolium, L. multiflorum (italian ryeagrass) and $L$. perenne (perrennial ryegrass) gender. These species freely cross between them and, as a result of the evolution and natural adaptation to different environments and crossing by breeders, show a continuous variation gradient, that goes from fully annual to fully perennial (Forrajeras..., 2010).

The southern Brazilian region is privileged for having a climate able to attend the necessities of different winter cultures, which present a higher nutritional value when compared to tropical species. As an example, Pires et al. (2006) and Bumbieris Junior et al. (2011) evidence big degradability rates in some winter grains, both highlighting great levels of soluble carbohydrates on the materials. Studies on ruminal kinetics of winter cereals are still scarce, though.

Countless models have been developed (Ellis et al., 1994; France et al., 1998; Mertens, 2005), and traditional mathematical functions have been readjusted for the utilization on the interpretation of ruminal kinetics. For the application of new prediction systems of exigencies on the nutrition of ruminants, new trustworthy estimates of ruminal degradability are needed. The systems used determine degradability values for each kind of food (Bumbieris Junior et al., 2011). However, more current and complex results are required, because there can be differences between cultivars of the same species of fodder, for instance.

In this context, more studies concerning ruminal degradation kinetics of different foods used in ruminant nutrition, especially the voluminous ones, are being held. This fact is useful for contributing with the balancing of diets and the needs of ruminant animals (Pires et al., 2006). On the other hand, most researches that evaluate species, cultivars and harvest systems are only based on biomass production, not considering the nutritional quality of the ruminal environment.

In their vegetative stage, winter grains count with high gross protein amounts (Fontaneli et al., 2009), reducing de necessity of supplementation with protein concentrates. Besides, this is the phase when the fiber has the biggest ruminal degradation potential and there is a great variation of this potential among the many species of winter grains, as well as harvesting managements (Bumbieris Junior et al., 2011). That being said, this research aims to evaluate the composition of fiber in neutral detergent, in situ digestibility of the structural components of the plant, as well as dry matter ruminal disappearance of fodder in five ryegrass fields, under different harvesting management systems for the production of haylage.

\section{MATERIALS AND METHODS}

The experiment was conducted by the Animal Production Center (NUPRAN) along with the Master's Degree Course in Agronomy in the Vegetable Production area, belonging to the Agrarian and Environmental Center of CenterWest State University (UNICENTRO), located in Guarapuava, state of Paraná, placed on Paraná's subtropical zone, under the geographic coordinates $25^{\circ} 23^{\prime} 02^{\prime \prime}$ south latitude and $51^{\circ} 29$ ' $43^{\prime \prime}$ west longitude, 1,026 meters of altitude.

The climate in the region, according to the Köppen classification is $\mathrm{Cfb}$ (Humid Mesothermic Subtropical), with cool summer seasons and moderated winter seasons, without a defined dry season and with severe frosts. The annual precipitation is around $1.944 \mathrm{~mm}$, and the average minimum temperature is $12.7^{\circ} \mathrm{C}$, while the maximum average temperature is $23 / 5^{\circ} \mathrm{C}$ with a relative humidity of $77 / 9 \%$.

The soil of the experimental area was classified as Typical Dark-Red Oxisol (Pott, 2007), and presented the following chemical characteristics ( 0 to 20 centimeters profile): $\mathrm{pH} \mathrm{CaCl}_{2}$ 0/01M: 4/7; P: $1 / 1 \mathrm{mg} \mathrm{dm}^{-3} ; \mathrm{K}^{+}$: 0/2cmolc $\mathrm{dm}^{-3}$; MO: $2 / 62 \mathrm{~g} \mathrm{dm}^{-3} ; \mathrm{Al}^{3+}: 0 / 0$ cmolc $\mathrm{dm}^{-3} ; \mathrm{H}^{+}+\mathrm{Al}^{3+}$ : 5/2 $\mathrm{cmolc} \mathrm{dm}^{-3}$; $\mathrm{Ca}^{2+}$ : 5/0cmolc $\mathrm{dm}^{-3} ; \mathrm{Mg}^{2+}$ : 5/0 $\mathrm{cmolc} \mathrm{dm}^{-3}$ and base saturation (V\%): $67 / 3 \%$. The objective was to evaluate the composition of fiber in neutral detergent, in situ digestibility of the structural components of the plant, as well as dry matter ruminal disappearance of fodder in five ryegrass fields, under different harvesting management systems for the production of haylage. 
The experimental design was the randomized blocks one, at a $5 \times 3$ factorial scheme, with five cultivars (cv.) of ryegrass Lolium multiflorum (cv. Barjumbo, cv. BarHQ, cv. Ribeye, cv. Potro and cv. Willians) associated with three harvesting management systems: 1 - single harvesting system at a pre-floral stage; 2 - double harvesting system, with a cut at vegetative stage and another at prefloral stage; and 3 - triple harvesting system, with a cut at vegetative stage, a cut at full vegetative stage and a cut at pre-floral stage, with three repetitions each. On each repetition, a parcel of $10.5 \mathrm{~m}^{2}(3 \mathrm{~m} \times 3.5 \mathrm{~m})$ was presented. The cultivars Ribeye and Willians are diploid hybrids and the cultivars BarHQ, Barjumbo and Potro are tetraploids hybrids.

Figure 1 shows the average rain occurrence in millimeters and the maximum and minimum temperature in Celsius degrees during the experimentation period, as well as the days of seeding, nitrogen application and cuts.

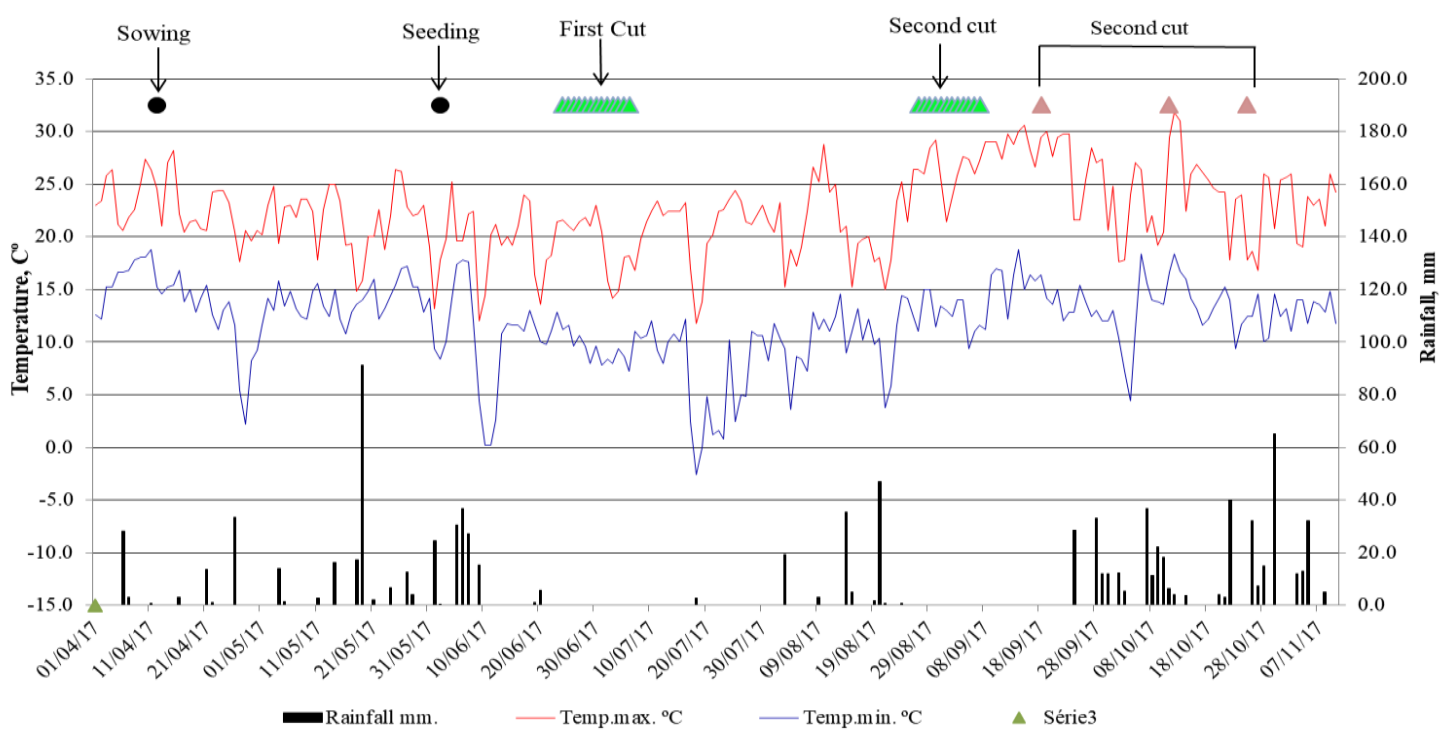

Source: Experimental station of SIMEPAR/UNICENTRO, Guarapuava, PR, 2017.

Figure 1. Average rainfall in millimeters and maximum and minimum temperature in Celsius occurred in the cultivation period.

The ryegrass cultivars were sown according to the agricultural zoning for the Guarapuava, Paraná region, in no-till system. The sowing was performed with a space of 0.17 meters between lines, in a seeding depth of approximately two centimeters and a seeding density of $22 \mathrm{~kg} \mathrm{ha}^{-1}$. Due to sowing, the fertilizing base was $280 \mathrm{~kg} \mathrm{ha}^{-}$ 1 of the 04-20-20 (N-P $\left.\mathrm{O}_{2} \mathrm{O}_{5}-\mathrm{K}_{2} \mathrm{O}\right)$ fertilizer, according to recommendations of the Fertility Commission of Soil in Santa Catarina and Rio Grande do Sul (Manual..., 2004). Nitrogen cover fertilization was made in a single application, 60 days after seeding, with $100 \mathrm{~kg} \mathrm{ha}^{-1}$ of urea (4600-00).

The weeds were chemically controlled by the use of Glifosate based herbicides (commercial product Roundup $\mathrm{WG}^{\circledR}: 3.0 \mathrm{~kg} \mathrm{ha}{ }^{-1}$ ) in the desiccation of the experimental area, 15 days before seeding, and in the culture management 30 days after planting, with the application of a metsulfuron-metyl based herbicide (commercial product Ally $\left.{ }^{\circledR}: 6.6 \mathrm{~g} \mathrm{ha}^{-1}\right)$.

The plants were cut at 10 centimeters from the ground, by hand, and according to each treatment, as seen in Figure. 1. The cuts performed at the vegetative stage and full vegetative stage reached a light interception of 90 to $95 \%$. The light interception (LI) was estimated by photosynthetically active radiation (PAR), measured by a digital linear heptometer model AccuPAR LP- 80 (Decagon, Devices).

Immediately after harvesting, a homogeneous sample of each unit was collected and sent to laboratory for determination of physical composition of the plant by the manual segmentation of the physical compounds stem, green leaves and senescent leaves, as well as dry 
matter percentage, by drying forced air greenhouse regulated at $55^{\circ} \mathrm{C}$ until the obtainment of constant weight.

Pre-dried samples of the original material were milled in a "Willey" type mill, with a 1 millimeter sieve, hence determining the fiber content in neutral detergent (FDN), fiber in acid detergent (FDA) and lignin (LIG) according to Silva e Queiroz (2009). From the referred values, the hemicellulose percentage was estimated (HEM) by difference between FDN and FDA and cellulose (CEL) by difference between FDN and LIG. The content of total digestive nutrients (NDT, \%) was obtained via the equation [NDT, \% $=87.84-(0.70 \times$ FDA $)]$, suggested by Bolsen et al. (1996).

The ruminal disappearance rate was determined by in situ technic, using nylon bags measuring $12 \mathrm{~cm} \times 8 \mathrm{~cm}$ and with 40 to $60 \mu \mathrm{m}$ pores, contending 5 grams of dry samples of each material, milled to $1 \mathrm{~mm}$, for posterior rumen incubation (Nocek, 1988). Incubation period used for fodder were $0,6,12,24,36$ and 48 hours, where 0-hour time represents the soluble fraction of dry matter. For such, a 48-mouth old calf was used, weighting 650 kilos, and bearing rumen fistulation.

The data were submitted to the $\mathrm{F}$ test, at $5 \%$ probability, through variation analysis (ANOVA) and then, when the difference was found, the Tukey test was performed in order to compare multiple pairs at $5 \%$ of significance, by means of the SAS (version 6.4) program. The data referring to the ruminal disappearance rate of dry matter were conducted by regression analysis (proc reg) in the statistics program SAS (version 6.4).

\section{RESULTS AND DISCUSSIONS}

Table 1 presents the data referring to the amount of hemicellulose e cellulose of the plants in different ryegrass fields under different harvesting management systems. There was no difference (P>0.05) among the cultivars at the pre-floral stage, showing an average level of $25.94 \%$ of hemicellulose. On the other hand, comparing the amount of cellulose, cvs. Barjumbo and Ribeye presented the highest levels $(\mathrm{P}<0.05)$ with $33.21 \%$ and $31.22 \%$, comparatively to cvs. BarHQ and Potro with $27.46 \%$ and $28.82 \%$, respectively.
It is also possible to observe in Table 1 that there were differences $(\mathrm{P}<0.05)$ among the harvesting management systems, given that the one-cut system showed a lower hemicellulose value at the pre-floral stage $(\mathrm{P}<0.05)$, with $21.45 \%$. Meanwhile, the management systems which received a cut at vegetative stage presented higher values of $27.34 \%$ in the two-cut system and $29.04 \%$ in the three-cut system. Lignin levels presented in Table 2 also show differences $(\mathrm{P}<0.05)$ among the evaluated cultivars. Cvs. BarHQ and Willians presented higher lignin levels at the pre-floral stage (12.24\% and $10.62 \%$, respectively). Comparatively, cv. Barjumbo had the lowest result, $8.38 \%$. According to Jung et al. (1983), lignin can inhibit microbial growth and digestive enzymes activity, forming, still in the rumen, complex such as carbohydrates, narrowing their digestion.

It is also observable that, comparing cultivars at pre-floral stage, cvs. Barjumbo and Willians showed the lowest concentration $(\mathrm{P}<0.05)$ of total digestible nutrients $(58.72 \%$ and $58.83 \%$, respectively). $\mathrm{Cv}$. Potro had the highest values $(60.73 \%)$, while the rest of the fields presented intermediate similar averages. In their studies Ball et al. (2007) found values of total digestible nutrients for ryegrass at vegetative stage that varied from $63 \%$ to $68 \%$ and of $59 \%$ to $62 \%$ at pre-floral stage, values that go against the results of the present study.

Generally, as the number of harvests grew, the concentration of total digestible nutrients at prefloral stage gradually decreased (Table 2), differing $(\mathrm{P}<0.05)$ among the harvesting management systems, while the levels of lignin raised, going from $61.30 \%$ and $7.68 \%$ in the onecut system, to $59.46 \%$ and $10.18 \%$ in the two-cut system and to $58.04 \%$ and $12.26 \%$ in the three-cut system. Based on these lignin levels, the percentage of fiber in neutral detergent and fiber in acid detergent (Table 3) increased in systems with two and three cuts, due to the amount of lignin, once cellulose e hemicellulose (Table 1) were constant. Velásquez et al. (2010), evaluating black oats under successive cuts, report that as the number of cuts was raised, the levels of lignin also escalated, leading to an in vitro digestibility reduction of dry matter. 
Table 1. Percentage of hemicellulose and cellulose of different ryegrass fields under different harvesting management systems

\begin{tabular}{|c|c|c|c|c|c|}
\hline \multirow[t]{2}{*}{ Cultivar } & \multirow{2}{*}{$\begin{array}{l}\text { Management } \\
\text { system }\end{array}$} & \multicolumn{3}{|c|}{ Stage at the cut } & \multirow[t]{2}{*}{ Average } \\
\hline & & Vegetative & $\begin{array}{c}\text { Full } \\
\text { vegetative }\end{array}$ & Pre-floral & \\
\hline & & \multicolumn{4}{|c|}{ Hemicellulose, $\%$ in dry matter } \\
\hline \multirow{3}{*}{ Willians } & One cut & - & - & 19.91 & \multirow{3}{*}{$25.70 \mathrm{a}$} \\
\hline & Two cuts & 19.81 & - & 27.94 & \\
\hline & Three cuts & 21.57 & 26.86 & 29.26 & \\
\hline \multirow{3}{*}{ Ribeye } & One cut & - & - & 19.08 & \multirow{3}{*}{$25.98 \mathrm{a}$} \\
\hline & Two cuts & 18.25 & - & 29.02 & \\
\hline & Three cuts & 18.78 & 28.12 & 29.86 & \\
\hline \multirow{3}{*}{ BarHQ } & One cut & - & - & 22.53 & \multirow{3}{*}{$26.98 \mathrm{a}$} \\
\hline & Two cuts & 17.49 & - & 30.51 & \\
\hline & Three cuts & 23.18 & 26.27 & 27.91 & \\
\hline \multirow{3}{*}{ Barjumbo } & One cut & - & - & 23.93 & \multirow{3}{*}{$26.35 \mathrm{a}$} \\
\hline & Two cuts & 20.57 & - & 25.87 & \\
\hline & Three cuts & 22.16 & 24.59 & 29.26 & \\
\hline \multirow{3}{*}{ Potro } & One cut & - & - & 21.79 & \multirow{3}{*}{$24.69 \mathrm{a}$} \\
\hline & Two cuts & 22.72 & - & 23.36 & \\
\hline & Three cuts & 23.55 & 27.94 & 28.92 & \\
\hline \multirow{3}{*}{\multicolumn{2}{|c|}{$\begin{array}{l}\text { One-cut system average } \\
\text { Two-cut system average } \\
\text { Three-cut system average }\end{array}$}} & & - & $21.45 \mathrm{~B}$ & \\
\hline & & & - & $27.34 \mathrm{~A}$ & \\
\hline & & & 26.76 & $29.04 \mathrm{~A}$ & \\
\hline \multirow{4}{*}{ Willians } & & \multicolumn{4}{|c|}{ Amount of cellulose, $\%$ in dry matter } \\
\hline & One cut & - & - & 30.78 & \multirow{3}{*}{$30.81 \mathrm{abc}$} \\
\hline & Two cuts & 15.81 & - & 31.02 & \\
\hline & Three cuts & 17.02 & 22.93 & 30.64 & \\
\hline \multirow{3}{*}{ Ribeye } & One cut & - & - & 31.22 & \multirow{3}{*}{$31.22 \mathrm{a}$} \\
\hline & Two cuts & 14.56 & - & 33.21 & \\
\hline & Three cuts & 15.30 & 17.64 & 29.23 & \\
\hline \multirow{3}{*}{ BarHQ } & One cut & - & - & 25.95 & \multirow{3}{*}{$27.46 \mathrm{c}$} \\
\hline & Two cuts & 15.98 & - & 25.18 & \\
\hline & Three cuts & 16.01 & 13.11 & 31.26 & \\
\hline \multirow{3}{*}{ Barjumbo } & One cut & - & - & 33.76 & \multirow{3}{*}{$33.21 \mathrm{a}$} \\
\hline & Two cuts & 16.73 & - & 32.78 & \\
\hline & Three cuts & 10.93 & 24.70 & 33.09 & \\
\hline \multirow{3}{*}{ Potro } & One cut & - & - & 29.49 & \\
\hline & Two cuts & 18.99 & - & 29.61 & $28.82 \mathrm{bc}$ \\
\hline & Three cuts & 20.83 & 20.84 & 27.37 & \\
\hline One-cut sys & average & & - & $30.24 \mathrm{~A}$ & \\
\hline Two-cut sy & average & & - & $30.36 \mathrm{~A}$ & \\
\hline Three-cut s & $\mathrm{m}$ average & & 19.84 & $30.32 \mathrm{~A}$ & \\
\hline
\end{tabular}

Averages followed by different capital letters in the column of comparison between cultivars differ by the Tukey 5\% test.

Averages followed by different lower case in the column, while comparing cut systems differ among themselves by the Tukey 5\% test. 
Table 2. Percentage of lignin and total digestible nutrients of different ryegrass fields under different harvesting management systems

\begin{tabular}{|c|c|c|c|c|c|}
\hline \multirow[t]{2}{*}{ Cultivar } & \multirow{2}{*}{$\begin{array}{l}\text { Management } \\
\text { system }\end{array}$} & \multicolumn{3}{|c|}{ Stage at the cut } & \multirow[t]{2}{*}{ Average } \\
\hline & & Vegetative & $\begin{array}{c}\text { Full } \\
\text { vegetative }\end{array}$ & Pre-floral & \\
\hline & & \multicolumn{4}{|c|}{ Lignin, $\%$ in dry matter } \\
\hline \multirow{3}{*}{ Willians } & One cut & - & - & 8.00 & \multirow{3}{*}{$10.62 \mathrm{ab}$} \\
\hline & Two cuts & 9.40 & - & 11.66 & \\
\hline & Three cuts & 6.46 & 9.46 & 12.19 & \\
\hline \multirow{3}{*}{ Ribeye } & One cut & 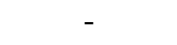 & - & 6.24 & \multirow{3}{*}{$9.06 \mathrm{bc}$} \\
\hline & Two cuts & 11.98 & - & 6.61 & \\
\hline & Three cuts & 12.13 & 13.47 & 14.32 & \\
\hline \multirow{3}{*}{ BarHQ } & One cut & - & - & 11.12 & \multirow{3}{*}{$12.24 \mathrm{a}$} \\
\hline & Two cuts & 5.32 & - & 13.65 & \\
\hline & Three cuts & 7.06 & 15.56 & 11.96 & \\
\hline \multirow{3}{*}{ Barjumbo } & One cut & - & - & 5.44 & \multirow{3}{*}{$8.38 \mathrm{c}$} \\
\hline & Two cuts & 9.77 & - & 8.63 & \\
\hline & Three cuts & 13.02 & 5.15 & 11.07 & \\
\hline \multirow{3}{*}{ Potro } & One cut & - & - & 7.58 & \multirow{3}{*}{$9.90 \mathrm{bc}$} \\
\hline & Two cuts & 5.32 & - & 10.37 & \\
\hline & Three cuts & 5.45 & 10.91 & 11.76 & \\
\hline \multirow{3}{*}{\multicolumn{2}{|c|}{$\begin{array}{l}\text { One cut system average } \\
\text { Two cuts system average } \\
\text { Three cuts system average }\end{array}$}} & & - & $7.68 \mathrm{C}$ & \\
\hline & & & - & $10.18 \mathrm{~B}$ & \\
\hline & & & 10.91 & $12.26 \mathrm{~A}$ & \\
\hline \multirow{4}{*}{ Willians } & & \multicolumn{4}{|c|}{ Total digestible nutrients, $\%$} \\
\hline & One cut & - & - & 60.69 & \multirow{3}{*}{$58.83 \mathrm{~b}$} \\
\hline & Two cuts & 70.19 & - & 57.96 & \\
\hline & Three cuts & 71.40 & 65.17 & 57.86 & \\
\hline \multirow{3}{*}{ Ribeye } & One cut & - & - & 61.62 & \multirow{3}{*}{$59.65 \mathrm{ab}$} \\
\hline & Two cuts & 69.26 & - & 59.97 & \\
\hline & Three cuts & 68.64 & 66.06 & 57.36 & \\
\hline \multirow{3}{*}{ BarHQ } & One cut & - & - & 61.89 & \multirow{3}{*}{$60.04 \mathrm{ab}$} \\
\hline & Two cuts & 72.93 & - & 60.65 & \\
\hline & Three cuts & 71.69 & 67.77 & 57.59 & \\
\hline \multirow{3}{*}{ Barjumbo } & One cut & - & - & 60.40 & \multirow{3}{*}{$58.72 \mathrm{~b}$} \\
\hline & Two cuts & 69.29 & - & 58.85 & \\
\hline & Three cuts & 71.08 & 66.94 & 56.93 & \\
\hline \multirow{3}{*}{ Potro } & One cut & - & - & 61.89 & \\
\hline & Two cuts & 70.82 & - & 59.85 & $60.73 \mathrm{a}$ \\
\hline & Three cuts & 69.44 & 65.62 & 60.45 & \\
\hline One cut syst & average & & - & $61.30 \mathrm{~A}$ & \\
\hline Two cuts sys & $\mathrm{n}$ average & & - & $59.46 \mathrm{~B}$ & \\
\hline Three cuts s & em average & & 66.31 & $58.04 \mathrm{C}$ & \\
\hline
\end{tabular}

Averages followed by different capital letters in the column of comparison between cultivars differ by the Tukey $5 \%$ test.

Averages followed by different lower case in the column, while comparing cut systems differ among themselves by the Tukey $5 \%$ test. 
Table 3. In situ digestibility of dry matter of stems and leaves, under a 48-hour incubation, of different ryegrass fields under different harvesting management systems

\begin{tabular}{|c|c|c|c|c|c|}
\hline \multirow[t]{2}{*}{ Cultivar } & \multirow{2}{*}{$\begin{array}{l}\text { Management } \\
\text { system }\end{array}$} & \multicolumn{3}{|c|}{ Stage at the cut } & \multirow[t]{2}{*}{ Average } \\
\hline & & Vegetative & $\begin{array}{c}\text { Full } \\
\text { vegetative }\end{array}$ & Pre-floral & \\
\hline & & \multicolumn{4}{|c|}{ In situ digestibility of stems, $\%$ of the dry matter } \\
\hline \multirow{3}{*}{ Willians } & One cut & - & - & 49.8 & \multirow{3}{*}{$46.9 \mathrm{a}$} \\
\hline & Two cuts & 87.9 & - & 49.7 & \\
\hline & Three cuts & 83.1 & 33.8 & 41.2 & \\
\hline \multirow{3}{*}{ Ribeye } & One cut & - & - & 56.9 & \multirow{3}{*}{$50.3 \mathrm{a}$} \\
\hline & Two cuts & 76.8 & - & 51.8 & \\
\hline & Three cuts & 79.9 & 40.9 & 42.1 & \\
\hline \multirow{3}{*}{ BarHQ } & One cut & - & - & 57.1 & \multirow{3}{*}{$47.3 \mathrm{a}$} \\
\hline & Two cuts & 84.6 & - & 47.3 & \\
\hline & Three cuts & 87.9 & 41.1 & 37.3 & \\
\hline \multirow{3}{*}{ Barjumbo } & One cut & - & - & 48.1 & \multirow{3}{*}{$44.4 \mathrm{a}$} \\
\hline & Two cuts & 80.1 & - & 47.5 & \\
\hline & Three cuts & 79.9 & 32.1 & 37.5 & \\
\hline \multirow{3}{*}{ Potro } & One cut & - & - & 58.3 & \multirow{3}{*}{$49.9 \mathrm{a}$} \\
\hline & Two cuts & 77.3 & - & 49.0 & \\
\hline & Three cuts & 75.7 & 42.3 & 42.3 & \\
\hline \multicolumn{2}{|c|}{ One cut system average } & & - & $54.0 \mathrm{~A}$ & \\
\hline \multicolumn{2}{|c|}{ Two cuts system average } & & - & $49.0 \mathrm{~A}$ & \\
\hline \multicolumn{2}{|c|}{ Three cuts system average } & & 38.1 & $40.1 \mathrm{~B}$ & \\
\hline
\end{tabular}

\begin{tabular}{|c|c|c|c|c|c|}
\hline \multicolumn{6}{|c|}{ In situ digestibility of green leaves (senescent leaves), $\%$ of the dry matter } \\
\hline \multirow{3}{*}{ Willians } & One cut & - & - & $67.3(44.3)$ & \multirow{3}{*}{$56.2 \mathrm{~b}(43.1 \mathrm{~b})$} \\
\hline & Two cuts & 81.3 & - & $55.1(46.7)$ & \\
\hline & Three cuts & 82.5 & $51.3(38.8)$ & $46.1(38.1)$ & \\
\hline \multirow{3}{*}{ Ribeye } & One cut & - & - & $77.3(48.5)$ & \multirow{3}{*}{$58.0 \mathrm{ab}(42.3 \mathrm{~b})$} \\
\hline & Two cuts & 90.2 & - & $53.0(42.4)$ & \\
\hline & Three cuts & 92.9 & $61.3(36.4)$ & $43.6(36.0)$ & \\
\hline \multirow{3}{*}{ BarHQ } & One cut & - & - & $84.0(60.0)$ & \multirow{3}{*}{$63.9 \mathrm{a}(50.3 \mathrm{a})$} \\
\hline & Two cuts & 90.8 & - & $58.0(50.5)$ & \\
\hline & Three cuts & 92.5 & $68.0(56.9)$ & $49.7(40.5)$ & \\
\hline \multirow{3}{*}{ Barjumbo } & One cut & - & - & $81.2(60.2)$ & \multirow{3}{*}{$63.4 \mathrm{a}(55.6 \mathrm{a})$} \\
\hline & Two cuts & 86.3 & - & $59.5(58.4)$ & \\
\hline & Three cuts & 88.8 & $65.2(54.2)$ & $49.5(48.4)$ & \\
\hline \multirow{3}{*}{ Potro } & One cut & - & - & $76.9(58.4)$ & \multirow{3}{*}{$60.5 \mathrm{ab}(53.5 \mathrm{a})$} \\
\hline & Two cuts & 82.2 & - & $57.2(56.1)$ & \\
\hline & Three cuts & 82.9 & $60.9(44.9)$ & $47.2(46.1)$ & \\
\hline \multicolumn{3}{|c|}{ One cut system average } & - & $77.3 \mathrm{~A}(54.3 \mathrm{~A})$ & \\
\hline \multirow{2}{*}{\multicolumn{3}{|c|}{ Two cuts system average }} & - & $56.5 \mathrm{~B}(50.8 \mathrm{~A})$ & \\
\hline & & Three cuts system average & $61.3(46.2)$ & $47.2 \mathrm{C}(41.8 \mathrm{C})$ & \\
\hline
\end{tabular}

Averages followed by different capital letters in the column of comparison between cultivars differ by the Tukey 5\% test.

Averages followed by different lower case in the column, while comparing cut systems differ among themselves by the Tukey $5 \%$ test.

Table 3 presents the data for in situ digestibility of dry matter of the structural components of the plant in different ryegrass fields under different harvesting management systems. No difference was found $(\mathrm{P}>0.05)$ for the digestibility of stems when comparing different cultivars. As for the green leaves, cvs. BarHQ and Barjumbo showed a higher digestibility $(63.4 \%$ and $63.9 \%$ respectively), differing $(\mathrm{P}<0,05)$ from $\mathrm{cv}$. Willians, which presented the lowest digestibility, 
with $562 \%$. Cvs. Ribeye and Potro showed a rate of $580 \%$ and $605 \%$, respectively. For senescent leaves, cvs. Barjumbo, Potro and BarHQ presented higher $(\mathrm{P}<005)$ digestibility $(556 \%$, $53 \%$ and $503 \%$, respectively), while cvs. Willians and Ribeye showed lower rates (431\% and $423 \%)$.

Table 3 also shows that the harvesting management system directly influenced the final digestibility of the plant, since the digestibility of stems in the one and two-cut systems presented higher values, with $54.0 \%$ and $49.0 \%$, both differing $(\mathrm{P}<0.05)$ from the three-cut system, with $40.1 \%$. Green leaves digestibility decreased $(\mathrm{P}<0.05)$ as the number of harvests was raised, going from $77.3 \%$ in the one-cut system, to $56.5 \%$ in the two-cut system and $47.2 \%$ in the three-cut system.

Concerning ruminal disappearance rate of dry matter of the plant in different ryegrass cultivars at the pre-floral stage (Figure. 2), it is possible to observe that cvs. Potro and BarHQ showed the highest concentration of soluble nutrients, number represented by the curve intercept, with $30.43 \%$ and $29.17 \%$, respectively. Cvs. Ribeye and Willians had the lowest intercepts $(25.61 \%$ and $25.62 \%$ ), what might be related to a bigger proportion of stems in the physical structure of the plants on those fields.

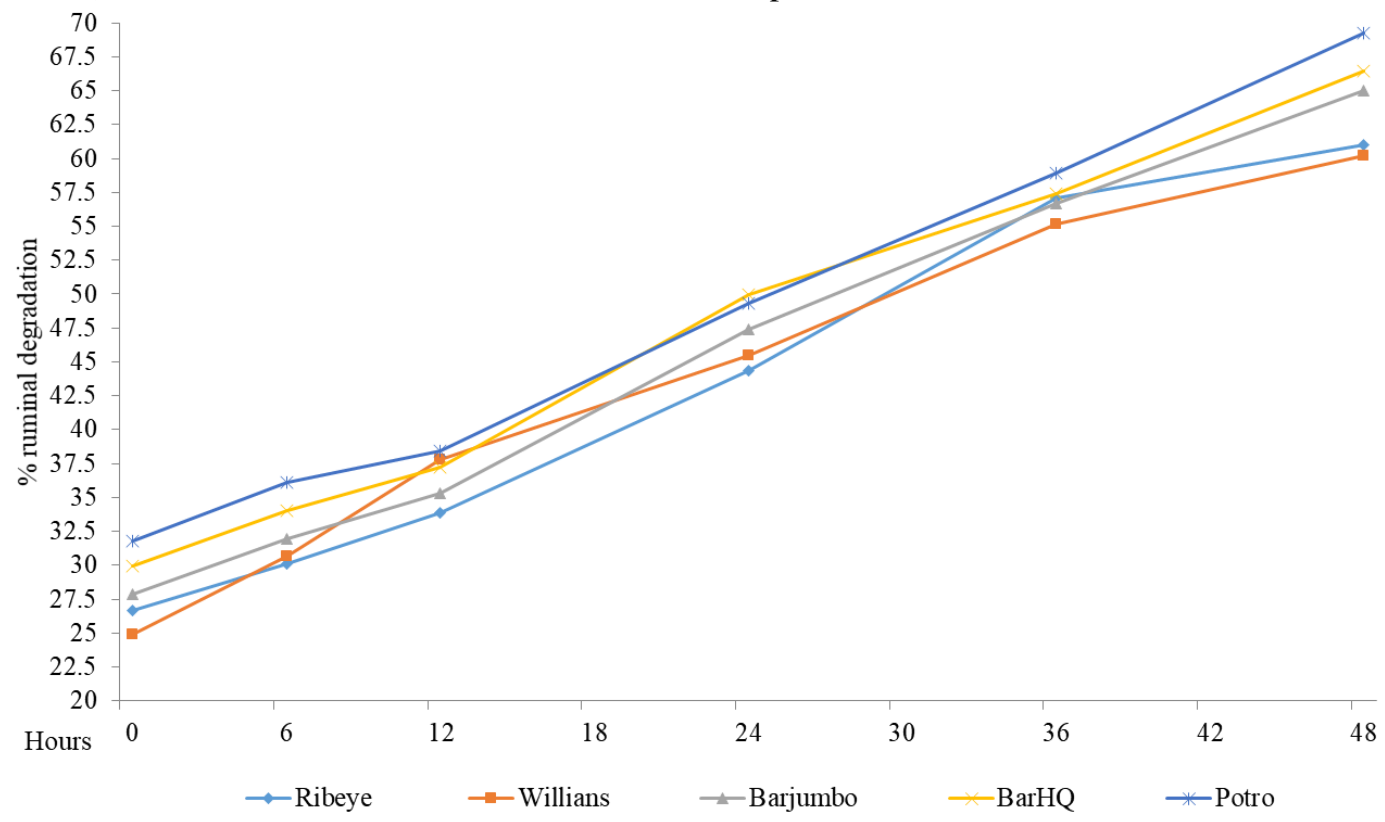

•DMS Ribeye: $25.6195+0.7821 \mathrm{H}\left(\mathrm{CV}: 22.71 \% ; \mathrm{R}^{2}: 0.6585 ; \mathrm{P}=0.0001\right)$, where $\mathrm{H}$ represents the incubation time, varying from 0 to 48 hours.

mDS Willians: $25.6250+0.7688 \mathrm{H}\left(\mathrm{CV}: 22.53 \% ; \mathrm{R}^{2}\right.$ : 0.6571; $\left.\mathrm{P}=0.0001\right)$.

A DMS Barjumbo: $26.9175+0.8084 \mathrm{H}\left(\mathrm{CV}: 21.12 \% ; \mathrm{R}^{2}: 0.6858 ; \mathrm{P}=0.0001\right)$.

x DMS BarHQ: $29.1704+0.7874 \mathrm{H}\left(\mathrm{CV}: 19.43 \% ; \mathrm{R}^{2}: 0.6931 ; \mathrm{P}=0.0001\right)$.

* DMS Potro: $30.4390+0.7976 \mathrm{H}\left(\mathrm{CV}: 15.45 \% ; \mathrm{R}^{2}\right.$ : 0.7746; $\left.\mathrm{P}=0.0001\right)$.

* “\% de degradação ruminal" stands for ruminal degradation percentage; "Horas" stands for Hours.

Figure 2. Ruminal disappearance rate of dry matter of different ryegrass fields at pre-floral stage.

Regarding harvesting management systems (Figure. 3), as the number of cuts was raised, the ruminal disappearance rate of dry matter of the plant after 48 hours diminished among harvesting management systems, going from $75.39 \%$ in the one-cut system, to $63.88 \%$ in the two-cut system and $53.89 \%$ in the three-cut system, respectively.
The value presented by the curve intercept stands for the concentration of soluble nutrients, so that as the number cuts was raised the amount of nutrients decreased, going from $37.09 \%$ in the one-cut system, to $27.25 \%$ in the two-cut system and $18.81 \%$ in the three-cut system, respectively. 


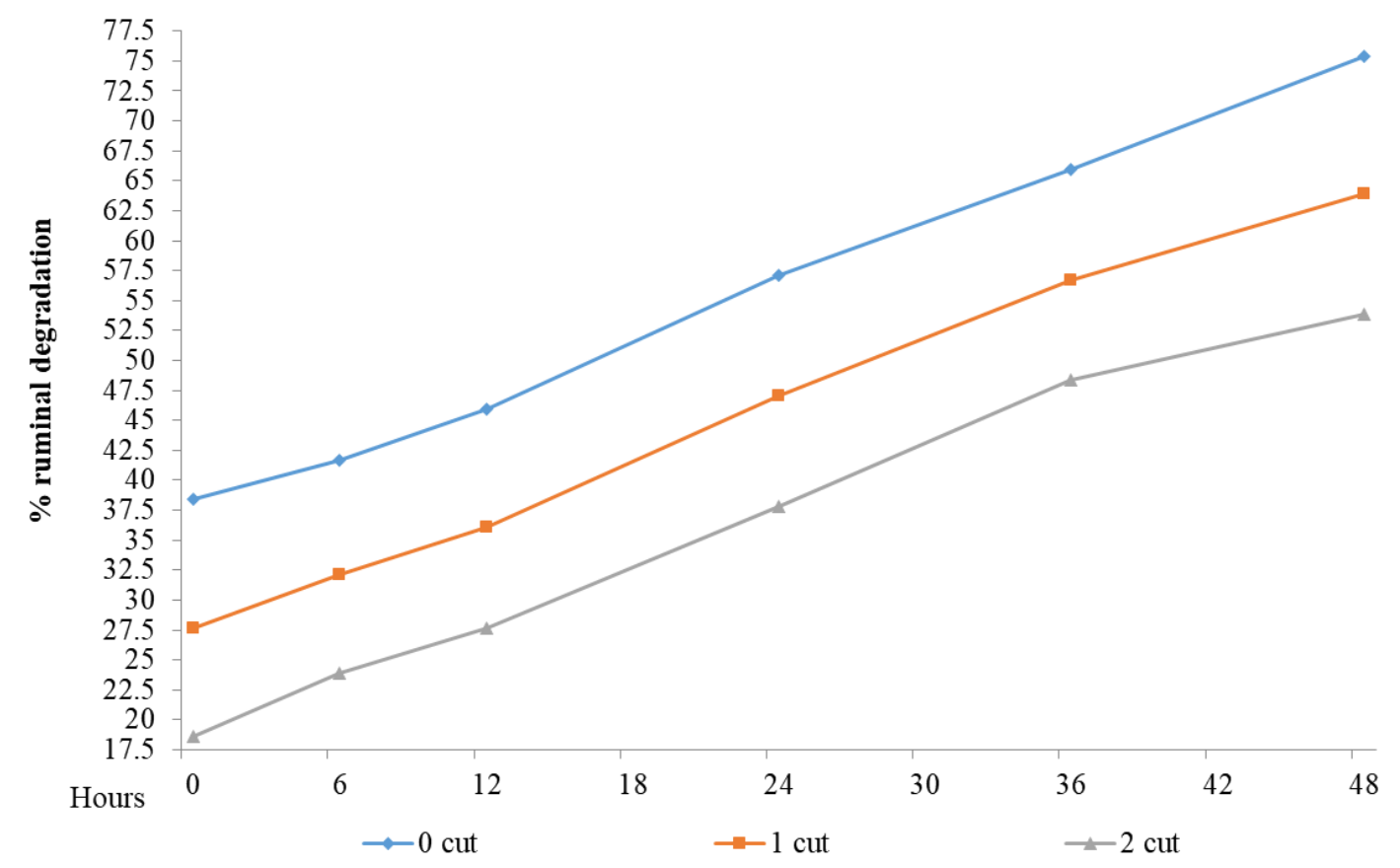

- DMS No cut: $37.0935+0,8015 \mathrm{H}\left(\mathrm{CV}: 8.26 \% ; \mathrm{R}^{2}: 0.9018 ; \mathrm{P}=0.001\right)$, where H represents incubation hour, varying from 0 to 48 hours.

- DMS One cut: $27.2503+0.7870 \mathrm{H}\left(\mathrm{CV}: 9.93 \% ; \mathrm{R}^{2}: 0.9020 ; \mathrm{P}=0.0001\right)$.

$\Delta$ DMS Two cuts: $18.8179+0.7666 \mathrm{H}$ (CV: $\left.14.75 \% ; \mathrm{R}^{2}: 0,86.23 ; \mathrm{P}=0.0001\right)$.

* "\% de degradação ruminal" stands for ruminal degradation percentage; "Horas" stands for Hours.

Figure 3. Percentage of disappearance of ryegrass dry matter submitted to different harvesting management systems at the pre-floral stage.

In general lines, ruminal disappearance rate of dry matter on plants obtained for the present essay can be rated as being of good quality, according to the Leng (1990) scale, which reports that fodder classified as low quality present values below $55 \%$. Some authors established relationships among anatomy, chemical composition and digestibility of fodder grass (Wilson et al., 1989). Correlations between the proportion of individual tissues, or in combination, and the nutritional entities were observed (Wilson et al., 1989; Queiroz et al., 2000). Generally, fibrous constituents of the fiber in neutral detergents (hemicellulose, cellulose and lignin) are negatively related to digestibility (Weiss, 1994; Queiroz et al., 2000; Alves de Brito et al., 2003).

\section{CONCLUSION}

Cvs. Ribeye and Barjumbo presented the highest levels of cellulose and cv. BarHQ showed the highest concentration of lignin. Regarding digestibility, cvs. Barjumbo and BarHQ reached better levels of green leaves digestibility and cv. Potro stood out for the great level of ruminal disappearance of fodder after 48 hours of incubation. In this harvesting management system, the raise of ryegrass cuts at the vegetative state determined growth in the lignin levels and reduction of total digestible nutrients and ruminal disappearance rates of dry matter in the resulting haylage. 


\section{REFERENCES}

ALVES DE BRITO, C.J.F.; RODELLA, R.A.; DESCHAMPS, F.C. Perfil químico da parede celular e suas implicações na digestibilidade de Brachiaria brizantha e Brachiaria humidicola. Rev. Bras. Zootec., v.32, p.1835-1844, 2003.

BALL, D.M.; HOVELAND, C.S.; LACEFIELD, G.D. Southern forages. 4.ed. Lawrenceville, Georgia: International Plant Nutrition Institute (IPNI), 2007. 322p.

BOLSEN, K.K.; ASHBELL, G.; WEINBERG, Z.G. Silage fermentation and silage additives-review. Asian Australas. J. Anim. Sci., v.9, p.483-494, 1996.

BRESSOLIN, A.P.S. Avaliação de populações de azevém quanto à tolerância ao alumínio tóxico $e$ estimativa de tamanho de amostra para estudos de diversidade genética com marcadores AFLP. 2007. 76f. Dissertação (Mestrado em Agronomia) Universidade Federal de Pelotas, Pelotas, RS.

BUMBIERIS JUNIOR, V.H.; OLIVEIRA, M.R.; JOBIM, C.C. et al. Perspectivas para uso de silagem de cereais de inverno no Brasil. In: SIMPÓSIO SOBRE PRODUÇÃO E UTILIZAÇÃO DE FORRAGENS CONSERVADAS, 2011, Maringá. Anais... Maringá: UEM/CCA/DZO, 2011. p.39-72.

ELLIS, W.C.; MATIS, J.H.; HILL, T.H.; MURPHY, M.R. Methodology for estimating digestion and passage kinetics of forages. In: FAHERY JR., G.C. Forage quality, evaluation and utilization. madison: american society of agronomy. 1994. p.682-756.

FONTANELI, R.S.; FONTANELI, R.S.; SANTOS, H.D. et al. Rendimento e valor nutritivo de cereais de inverno de duplo propósito: forragem verde e silagem ou grãos. Rev. Bras. Zootec., v.38, p.2116-2120, 2009.

FORRAJERAS: catálogo de cultivares 2010. Montevideo: INIA, 2010. 1 CD-ROM.

FRANCE, J.; DIJKSTRA, J.; DHANOA, M.S. et al. Biomathematical applications in ruminant nutrition. $J$. Franklin Ins., v.335, p.241-258, 1998.

JUNG, H.J.G.; JAHEY J.R.; SONG, G.C. Nutricional implications of phenolic monomers and lignin. A review. J. Anim. Sci., v.57, p.206-219, 1983.
LENG, R.A. Factors affecting the utilization of "poorquality" forages by ruminants particularly under tropical conditions. Nutr. Res. Rev., v.3, p.277-303, 1990.

MANUAL de adubação e calagem para os Estados do Rio Grande do Sul e de Santa Catarina. 10.ed. Porto Alegre: CQFS RS/SC, 2004. 404p.

MERTENS, D.R. Rate and extent of digestion. In: DIJKSTRA, J.; FORBES, J.M.; FRANCE, J. Quantitative aspects of ruminant digestion and metabolism. Wallingford: CAB International Wallingford, 2005. p.13-47.

NOCEK, J.E. In situ and other methods to estimate ruminal protein and energy digestibility. A review. $J$. Dairy. Sci., v.71, p.2051-206, 1988.

PIRES, A.J.V.; REIS, R.A.; CARVALHO, G.G.P.D. et $a l$. Degradabilidade ruminal da matéria seca, da fração fibrosa e da proteína bruta de forrageiras. Pesqu. Agropecu. Bras., v.41, p.643-648, 2006.

POTT, C.A.; MÜLLER, M.M.L.; BERTELLI, P.B. Adubação verde como alternativa agroecológica para recuperação da fertilidade do solo. Rev. Amb., v.3, p.5163, 2007.

QUEIROZ, D.S.; GOMIDE, J.A.; MARIA, J. Avaliação da folha e do colmo de topo e base de perfilhos de três gramíneas forrageiras. 2. Anatomia. Rev. Bras. Zootec., v.29, p.61-68, 2000

SILVA, D.J.; QUEIROZ, A.C. Análise de alimentos, métodos químicos e biológicos. Viçosa: Universidade Federal de Viçosa, 2009. 235p.

VELÁSQUEZ, P.A.T.; BERCHIELLI, T.T.; REIS, R.A. et al. Composição química, fracionamento de carboidratos e proteínas e digestibilidade in vitro de forrageiras tropicais em diferentes idades de corte. Rev. Bras. Zootec., v.39, p.1206-1213, 2010.

WEISS, W.P. Estimation of digestibility of forages by laboratory methods. In: FAHEY JR., G.C.; COLLINS, M.; MERTENS, D.R. et al. (Eds.). Forage quality evaluation and utilization. Nebraska: American Society of Agronomy, 1994. p.644-651.

WILSON, J.R.; ANDERSON, K.L.; HACKER, J.B. Dry matter digestibility in vitro of leaf and stem of buffel grass (Cenchrus ciliares) and related species and its relation to plant morphology and anatomy. Aust. J. Agri. Res., v.40, p.281-291, 1989. 